\title{
No time to be squabbling
}

A RoUTine day at the United Nations in New York? No, a session at the Congress of the World Meteorological Organisation, one of the UN's specialised agencies, held recently in Geneva. At the end of the debate, South Africa was suspended from WMO until it renounces its policy of racial discrimination. The voting was 66 in favour, 25 against and 14 abstentions. In the same session the congress voted $81-14$ to invite to WMO meetings observers from National Liberation Movements recognised by the Organisation of African Unity or the League of Arab States. Thus do some international scientific organisations conduct themselves these days; already the Food and Agricultural Organisation, UNESCO and the World Health Organisation have taken comparable restrictive measures against South Africa, and the recent Israel affair still causes a good deal of embarrassment at UNESCO.

The very existence of South Africa is, of course, an affront to a majority of nations-indeed many of those who voted to retain South Africa in membership spoke of their abhorrence of her racial policies. And the depth of feeling can never be fully appreciated by the unoppressed whites of Europe. Nonetheless these latter also have deep feelings about the nature of science and the need for its pursuit to be free from politicisation, especially of the amateurish and self-congratulatory type. It is to the credit of the International Council of Scientific Unions (ICSU) that it has thus far been able to stand clear of most of the political nonsenses-although this has been at the expense of China's membership, since she resolutely refuses, despite all invitations, to be alongside Taiwan in the same meetings. It is also to the credit of the UNESCO staff that what gets to the conference table in that assembly has so far generally been universally acceptable.

But the question is bound to be asked-is the international science scene becoming increasingly politicised these days?
Was it ever otherwise, retort some of the wiser folk in the business-it's just that these days the west can be outvoted every time, so the politics are not those favourable to western countries; remember how the west used to vote to exclude China. This is a sane historical point of view, and history teaches us why people's present attitudes are what they are. Historical perspective, however, also gives us the opportunity to learn from the past in order not to re-live it. And one thing that ought to have been learnt is that the isolation of scientific and other intellectual pursuits, particularly from bodies which claim to be representative, profits no-one and is a futile gesture in the face of strong regimes.

There is another reason why the politicisation of science is particularly inappropriate at present. If voting in United Nations bodies were regularly to divide broadly such that developing countries, with their built-in majority, were able to force the pace against the developed countries which supply the money, then it is not inconceivable that an issue could arise on which the developed world decided it had had enough and would keep its money to itself. As yet there is no sign of this, but UNESCO is bound to be particularly closely watched in the coming year with its new Director-General, Mr M'Bow from Senegal, representative of the shift of power towards the developing countries. He will need to pursue a diplomatic path, and will not be helped by divisive confrontation.

But lest it be said that we are defining divisiveness as that which comes from the developing world, it should be added that some of the initiatives of the developed world seem only capable of generating bad feelings. Massachusetts Institute of Technology, which is negotiating a development contract for water resources in Saudi Arabia, is, it is reported, threatening that any act of religious discrimination will cause the contract to be cancelled. Saudi Arabia can hardly welcome Jews with open arms; it surely behoves MIT to use restraint and not to trigger confrontation by insisting on sending them. 